\title{
Performance of Change Through the G.I. Bill
}

\author{
Jillian B. Smith \\ University of Texas at Austin
}

The Servicemen's Readjustment Act of 1944, referred to as the "G.I. Bill," persists in the American memory as a monumental act of legislation. The bill welcomed millions of veterans into the middle class, and many Americans now praise it as a benevolent reward for military service. Passed unanimously, the G.I. Bill gained broad support despite a conservative backlash against the New Deal. ${ }^{1}$ The bill expanded the federal government's welfare for veterans by providing low-cost mortgages, low-interest loans, unemployment compensation, and tuition payments to all World War II veterans. ${ }^{2}$ Such support illustrated a change in veterans' legislation and suggested the federal government sought to celebrate its servicemen.

In reality, the bill preserved existing government responsibilities - a prewar balance of power, a duty to rehabilitate disabled veterans, and a distinction between veterans and civilians in legislation. Despite its progressive appearance, the bill did nothing to change the ideology of veterans' legislation. The bill's architects anticipated a postwar need for increased rehabilitation but acted with pragmatism to protect the economy. The bill sought to limit veterans' dependence on the state and maintain the conservative, prewar social contract between the federal government and veterans, including age-old disparities of race.

The G.I. Bill emerged as a continuation of historic debates over the government's role in veterans' affairs and preserved the duty to provide for disabled veterans. The Bonus March of 1932 revealed destitution among WWI veterans. With the memory of WWI veterans demanding more support from their government, the federal government used the G.I. Bill as an economic defense against later protests. As lawmakers approached WWII veterans' legislation, they attempted to avoid repeating the politicization of veterans. ${ }^{3}$

\footnotetext{
1 “TO PASS S. 1767, THE SERVICEMAN'S READJUSTMENT ACT OF 1944, ... -- House Vote \#120 -- May 18, 1944." GovTrack.us. Accessed April 5, 2020. https://www.govtrack.us/congress/votes/78-1944/h120.

${ }^{2}$ Kathleen J. Frydl, The GI Bill, (New York City: Cambridge University Press, 2009), 1-2.

${ }^{3}$ Frydl, The GI Bill, 79.
} 
Between the Civil War and First World War, veterans' policy focused on politics, not need. Until WWI, the federal government administered pensions for veterans disabled by war and their widows. ${ }^{4}$ These pensions furnished financial support for families rendered unable to support themselves after service in the war. Civil War veterans' legislation, enacted in 1862, assisted men disabled in service to the Union, and the restricted payment continued the traditional approach to pensions. ${ }^{5}$ Congress expanded Civil War pensions to include veterans disabled after service and all surviving veterans by $1890 .^{6}$

The power of the Grand Army of the Republic (GAR), the largest veterans' lobby with over 400,000 members, emerged following the Civil War. ${ }^{7}$ The GAR supported its membership and demanded increased access to pensions, which jeopardized public admiration of veterans. ${ }^{8}$ As pensions increased, civilians perceived veterans as burdens who abused tax dollars for comfort. ${ }^{9}$ The GAR's strength derived from its numbers, and as a result, the GAR presented the federal government with a new constituency that could win elections. It utilized the influence of its members to gain expanded pensions, guaranteeing legislators the veterans' vote. Pension lawyers saw an opportunity to increase their business, and joined forces with the GAR, creating a powerful lobby to influence veterans' pension legislation. Thanks to their efforts, the 1879 Arrears of Pension Act expanded pensions to include all Union veterans with disabilities, regardless of when they were disabled. The Arrears Act announced intentions to lessen inequitable pension access, a process different across the nation, but in reality, it sought to satisfy the GAR and pension lawyers. ${ }^{10}$

The GAR continued to advocate for greater payments. After the Arrears Act, veterans' legislation morphed into patronage, and congressmen continued to appease the GAR. ${ }^{11}$ Civilians thought such legislation raided the U.S. Treasury, as pensions consumed an ever-increasing portion of the national budget. ${ }^{12}$ The public perceived financial support to able-bodied servicemen as veterans' greed. ${ }^{13}$ Legislators avoided excess payments following the corruption of Civil War pensions, which illustrated a pivot in veterans' legislation. The idea influenced the later WWI compensation legislation to redefine why veterans deserved support from national institutions. $^{14}$

\footnotetext{
${ }^{4}$ Glenn C. Altschuler and Stuart M. Blumin, The GI Bill: A New Dealfor Veterans, (New York City: Oxford University Press, 2009), 13.

5 Theda Skocpol, “America's First Social Security System: The Expansion of Benefits for Civil War Veterans," Political Science Quarterly, Vol. 108, no. 1 (Spring 1993), 92; Altschuler, The GI Bill, 19.

6 Frydl, The GI Bill, 18.

7 "Grand Army of the Republic History.” Sons of Union Veterans of the Civil War, January 9, 2014. http://www.suvcw.org/?page_id=167.

${ }^{8}$ Michael J. Bennett, When Dreams Came True: The GI Bill and the Making of Modern America, (Brassey's Inc., 1996), 38.

${ }^{9}$ Altschuler, The GI Bill, 23.

${ }^{10}$ Skocpol, “America’s First Social Security System," 102.

${ }^{11}$ Altschuler, The GI Bill, 22.

12 Bennett, When Dreams Came True, 40-41.

13 Ibid., 38.

14 Ibid., 60-61.
} 
Continuous revisions to pension policy revealed lawmakers' greed. By the end of the $19^{\text {th }}$ century, pensions constituted almost a fifth of the national budget, further alienating civilians from veterans. ${ }^{15}$ In 1924, Congress enacted the World War Adjusted Compensation or "Bonus" Act. Payments to servicemen embodied the practical consideration of the loss of often higher domestic wages during the war. ${ }^{16}$ The bonus payment, delayed for 21 years to allow the appropriation to mature much like a bond, compensated veterans for lost economic security from their military service.

The "Bonus" Act intended to avoid the corruption of Civil War pensions that continued to define beneficiaries. The legislation departed from gratitude and instead responded to lost income stemming from service. By 1930, however, the onset of the Great Depression introduced new challenges as many veterans demanded a response to their immediate need. Veterans began to seek an advance on their bonuses after losing their jobs. Congress refused to act because it was unable to pay the bonuses until 1945. ${ }^{17}$ Then Navy Secretary Franklin D. Roosevelt argued the payment to veterans, let alone an advance, would tarnish veterans' honor; the federal government avoided immediate payment to veterans to shirk any appearance of corruption. ${ }^{18}$ Preserving the original payday may have upheld veterans' dignity, but it also suggested the federal government's loyalty resided with appearances, not the needs of veterans. ${ }^{19}$

Desperate veterans joined together in the Bonus March of 1932, an organized protest in Washington D.C., to call for a thirteen-year advance. Congress again rejected their pleas, and the government responded with tanks and drawn bayonets. It refused to serve its veterans apart from necessity born of disability. ${ }^{20}$ While the progressive-era Congress passed the Bonus to assist veterans with future economic instability, the delayed payment shirked appearances of additional compensation for service. ${ }^{21}$ The social contract focused on loss and restricted federal duty to veterans who could no longer provide for themselves. In an effort to avoid the corruption of Civil War pensions, lawmakers overcorrected and excluded veterans from social welfare. The patronage of Civil War pensions tainted monetary displays of gratitude. ${ }^{22}$ As national leaders believed broad and immediate financial support fueled the corruption from the Civil War, many sought to preserve disability as the guardrail to utilizing veterans' legislation.

Those guardrails widened under President Franklin D. Roosevelt's New Deal. It broadened the powers of the federal government through a series of progressive social policies to help Americans weather the Great Depression. The New Deal revised the social contract between civilians and their government. FDR claimed the government must take initiative to uplift its people in a crisis not as a matter of charity but of social obligation.

${ }^{15}$ Bennett, When Dreams Came True, 40-41.

${ }^{16}$ Altschuler, The GI Bill, 27.

${ }^{17}$ Bennett, When Dreams Came True, 57.

${ }^{18}$ Ibid.

${ }^{19}$ Ibid.

${ }^{20}$ Davis R. B. Ross, Preparing for Ulysses: Politics and Veterans During World War II (New York City: Columbia University Press, 1969), 17.

${ }^{21}$ Altschuler, The GI Bill, 26-27.

${ }^{22}$ Bennett, When Dreams Came True, 61. 
While FDR extended federal support to many underserved communities, he neglected veterans. The exclusion continued the legacy, championed by the large veterans' organization, the American Legion, of separating civilians from veterans in all policy. ${ }^{23}$ Such separation attempted to perpetuate veterans' exceptionalism, which, during the New Deal, came at the expense of lost welfare benefits. ${ }^{24}$ Roosevelt continued to believe that social welfare diminished veterans' patriotism to a transaction; he thought financial gratitude echoed the corruption of Civil War pensions. ${ }^{25}$ As the New Deal extended welfare and support for civilians, the federal government preserved its traditional social contract for veterans, providing for the disabled among them.

The onset of the Second World War helped end the Great Depression and provided Americans with new jobs essential to the war effort. Domestic employment benefitted from millions of soldiers leaving the job market because servicemen left their jobs for onceunemployed civilians to fill. The postwar economy lacked the capacity to employ returning veterans, and the Depression fueled fears of an economy too weak for its population. As the war effort helped the nation recover from the Great Depression, the demobilization of 16 million unemployed veterans threatened national stability. Without a job waiting for them, veterans returning home faced unemployment and economic disability whereas civilians kept higherpaying jobs throughout the war.

In response to economic anxiety, national leaders understood that new veterans' legislation must account for their re-entry in the job market. ${ }^{26}$ Support for veterans could defend against the possibility of a second Great Depression. As the widespread unemployment instigated the Bonus Army's march on Washington, lawmakers acknowledged veterans' ability to organize against the federal government. Having watched unemployed veterans across Germany and Italy embrace fascism during the Great Depression, the U.S. anticipated the possibility of populist sympathies among destitute veterans. ${ }^{27}$ Anxiety about how to keep the economy afloat and veterans peaceful guided lawmakers to reconsider the nature of veterans' rehabilitation. ${ }^{28}$ The G.I. Bill originated from such fears.

Although the restricted definition of the federal government's obligations to veterans remained unchanged, veterans' lobbyists began to challenge the definition of "disabled." As the WWI Bonus accounted for loss of a higher-paying job as an economic impairment, the American Legion began to reimagine who was disabled by their service. ${ }^{29}$

Seeking more expansive support from the federal government, the Legion broadened its interpretation of handicap to include mental, educational, and economic impairments resulting

\footnotetext{
${ }^{23}$ Frydl, The GI Bill, 8.

${ }^{24}$ Ibid.

${ }^{25}$ Ibid., 57.

${ }^{26}$ Frydl, The GI Bill, 137.

${ }^{27}$ Keith W. Olsen, The G.I. Bill, the Veterans, and the Colleges, (Lexington: The University of Kentucky Press, 1974), 4.

${ }^{28}$ Bennett, When Dreams Came True, 129.

${ }^{29}$ Altschuler, The GI Bill, 26.
} 
from service in WWII. ${ }^{30}$ Claiming wartime service incapacitated all soldiers, the Legion separated veterans from citizens by demanding that policies treat them as distinct classes and advocated for the protection of the national wellbeing. ${ }^{31}$ The separation between veterans and civilians stemmed from the Legion's ideal of veterans' exceptionalism, which served their membership by suggesting veterans belonged to a social class distinct from ordinary citizens. ${ }^{32}$ The New Deal never distinguished between the two groups, but veterans' legislation did, allowing the Legion to pursue ambitious provisions as lawmakers attempted to compensate returning soldiers.

The Legion capitalized on anxiety about the economic shocks millions of unemployed G.I.s could bring. The Legion enlisted newspaper mogul William Randolph Hearst to organize a public campaign in support of veterans' legislation. Hearst spread the notion of battle fatigue as a threat to the nation by suggesting that returning men might be bitter, psychotic, and aggressive. ${ }^{33}$ Veterans could trigger a return of the Great Depression and they could bring the bloodshed of a global war home. The Legion used such fears to advocate for their expanded definition of disabled veterans. The rhetoric suggested that the hardships and trauma of war suffered by veterans necessitated economic assistance as they readjusted to civilian life. ${ }^{34}$ Veterans' legislation became a means to protect the entire nation, not just the returning servicemen.

The G.I. Bill highlighted the Legion's legislative priorities and excluded the other veterans' organizations from the final legislative effort. As the Legion attempted to change the nature of veterans' legislation during WWII, the Veterans of Foreign Wars (VFW) joined forces with other veterans' organizations to oppose new Legion efforts. ${ }^{35}$ The VFW teamed up with the Disabled American Veterans, Military Order of the Purple Heart, and Regular Veterans Association for fear that the Legion's broad definition of disability from service would distract legislative attention from physically disabled veterans. ${ }^{36}$

For its part, the Legion departed from the otherwise-united organizations because it believed readjustment presented a problem for all veterans. ${ }^{37}$ With over an eighth of all soldiers discharged on account of psychological deficiency, often cases of battle fatigue, the Legion feared veterans would fail to integrate into society. ${ }^{38}$ War experiences alienated veterans before

\footnotetext{
${ }^{30}$ Frydl, The GI Bill, 112.

${ }^{31}$ Lawrence J. Fenlon, "Summary of Proceedings: Twenty-Fifth Annual National Convention of the American Legion: Report of Committee on Employment," September 23, 1943, found in The American Legion Digital Archive, https://archive.legion.org/, Accessed April 4, 2020, quote from page 72.

${ }^{32}$ Frydl, The GI Bill, 8.

${ }^{33}$ Ibid., 111.

${ }^{34}$ Ibid., 112.

${ }^{35}$ Virginia Held and Suzanne Mettler, Soldiers to Citizens: The G.I. Bill and the Making of the Greatest Generation, (New York City: Oxford University Press, 2005), 20.

${ }^{36}$ Meredith Hindley, "How the GI Bill Became Law in Spite of Some Veterans' Groups," HUMANITIES: The Magazine of the National Endowment for the Humanities, Vol. 35, no. 4, (July/August 2014).

${ }^{37}$ Frydl, The GI Bill, 113.

${ }^{38}$ Christopher P. Loss, Between Citizens and the State: The Politics of American Higher Education in the $20^{\text {th }}$ Century, (Princeton: Princeton University Press, 2012), 111.
} 
they returned home, and many men felt unable to reconnect with civilian life upon return. ${ }^{39}$ At the 1943 American Legion Convention, Governor Prentice Cooper (D-TN) called upon upcoming legislation to "secure a sound and enduring peacetime," by creating opportunities for veterans to seek work and economic security to promote their reintegration into society. ${ }^{40}$ Departing from other organizations' calls to protect a limited number of individuals, the Legion distinguished itself as the lobby that would protect the nation and all of its veterans.

The opposing veterans' organizations sought legislation specific to disabled veterans because a more inclusive bill would impede their access to rehabilitation. ${ }^{41}$ Several organizations advocated for a bonus for physically disabled veterans. However, Congress rejected action similar to the failed 1924 Bonus Act. ${ }^{42}$ Offering an alternative, the Legion presented new ideas for veterans' legislation, which provided federal welfare to all veterans. The Legion parted with all other veterans' organizations and lead the formulation and passage of the G.I. Bill on its own.

The Legion benefitted from the alignment between their advocacy and the Roosevelt Administration's proposals for integrating returning soldiers into the economy. In 1943, the National Resources Planning Board (NRPB), a progressive research agency within the executive branch responsible for many New Deal programs, suggested the federal government owed vocational training and education to veterans to equip them for the postwar economy. ${ }^{43}$ Since the NRPB's solution promoted veterans' exceptionalism by distinguishing them for such benefits, the Legion embraced the recommendations. ${ }^{44}$ The unexpected alignment between major progressive and conservative voices further illustrated the G.I. Bill as a necessary solution to impending issues, not an ideological initiative.

Fearful of another Great Depression, FDR pivoted to support increased veterans' programming. Roosevelt's endorsement of NRPB suggestions put him at odds with the conservative leadership in Congress. Conservatives defunded the NRPB in 1943 to avoid a resurgence of New Deal-styled policies. ${ }^{45}$ Roosevelt began following the Legion's advocacy for veterans' programming to distance himself from the appearance of seeking increased executive power. ${ }^{46}$ The organization possessed a history of conservatism that advocated for individual liberty, states' rights, and limited social welfare. ${ }^{47}$ The Legion maintained friendships with both the president and Congress, balancing their support for expansive legislation with the traditional balance of power.

\footnotetext{
${ }^{39}$ Frydl, The GI Bill, 110.

${ }^{40}$ Prentice Cooper, "Summary of Proceedings: Twenty-Fifth Annual National Convention of the American Legion: Address of the Honorable Prentice Cooper," September 21, 1943, found in the American Legion Digital Archive, https://archive.legion.org/, Accessed April 4, 2020, quote from page 27.

${ }^{41}$ Hindley, "How the GI Bill Became Law in Spite of Some Veterans' Groups."

${ }^{42}$ Ross, Preparing for Ulysses, 103.

43 Theodore R. Mosch, The G.I. Bill: A Breakthrough in Educational and Social Policy in the United States, (Hicksville: Exposition Press, 1975), 31.

${ }^{44}$ Frydl, The GI Bill, 113.

${ }^{45}$ Held, Soldiers to Citizens, 17.

${ }^{46}$ Olsen, The G.I. Bill, the Veterans, and the Colleges, 12.

${ }^{47}$ Held, Soldiers to Citizens, 20.
} 
Building on their electoral success in 1942, resurgent conservatives in Congress wanted to avoid expanding social welfare programs that strengthened executive power. The Republican Party platform of 1944 claimed that "four more years of New Deal policy would centralize all power in the president... subject[ing] every act of every citizen to regulation by his henchmen." ${ }^{48}$ The dissension against expanding the New Deal and FDR's authority highlighted the need for conservative support for a veterans' affairs bill to pass in Congress. The Legion's lobbying against the New Deal strengthened their credibility among conservatives. Legion leadership insisted post-war veterans' legislation must preserve individual freedom and denounce wartime federal power. ${ }^{49}$ Such requirements countered the appearance of federal intrusion on veterans. The Legion thus emerged as the leader of WWII veterans' legislation and gathered support by combining multiple interests to solve the threat of the return of the Great Depression.

As lawmakers began to draft WWII veterans' legislation, they followed the Legion's "G.I. Bill of Rights." The language, similar to FDR's "Economic Bill of Rights," drew inspiration from his "Four Freedoms" to better appeal to liberals. ${ }^{50}$ The omnibus bill fulfilled many of the NRPB recommendations to assist the transition from a wartime to a peacetime economy. However, the Legion and NRPB acted with different intentions. The Legion sought to expand federal benefits for all veterans while maintaining a conservative balance of power that favored states' rights. The Legion's approach drew upon the extant commitment to assist men disabled in wartime service. ${ }^{51}$ While both the Legion and NRPB advocated increased federal benefits for returning veterans, the Legion explained federal funding for rehabilitation programs as rights, not welfare. The Legion tailored their rhetoric to imply veterans remained independent of the federal government, despite the uniformity of benefits nationwide.

Such rhetoric strengthened conservative endorsement in Congress for the Legion's proposals. Just as Civil War pensions provided financial aid for disabled soldiers and the WWI bonus intended to compensate for lost jobs, the G.I. Bill of Rights included provisions for economic, educational, and social disabilities accrued during the war. ${ }^{52}$ The Republican Party expressed concern regarding the return of the Great Depression at its 1944 convention, arguing that the assurance of peacetime work and livelihood for veterans was essential "to establishing liberty at home." 53 The right to work protected Americans by warding off threats of depression and fascism. Framing such assistance as the right of veterans garnered conservative support because it depicted federal expansion as limited protection, not boundless intervention. ${ }^{54}$ The Legion centered its message on the rights of veterans to calm conservative fears of an expanding welfare state under FDR's command.

\footnotetext{
48 "Republican Party Platform of 1944." Republican Party Platform of 1944 | The American Presidency Project, June 26, 1944. https://www.presidency.ucsb.edu/documents/republican-party-platform-1944.

${ }^{49}$ Bennett, When Dreams Came True, 128, Frydl, The GI Bill, 89

${ }^{50}$ Olsen, The GI Bill, the Colleges, and the Veterans, 12.

${ }^{51}$ Ibid., 112.

${ }^{52}$ Mosch, The G.I. Bill, 42.

53 "Republican Party Platform of 1944." Republican Party Platform of 1944 | The American Presidency Project, June 26, 1944. https://www.presidency.ucsb.edu/documents/republican-party-platform-1944.

${ }^{54}$ Frydl, The GI Bill, 118.
} 
While the enumerated rights presented by the Legion mirrored NRPB recommendations, its rhetorical strategy silenced conservative criticism. In light of the expansion of federal programs, conservatives pursued a bill that limited veterans' dependence on the federal government. ${ }^{55}$ Public communications explaining these new rights to veterans, such as a pamphlet from the Army Times entitled "The GI Bill of Rights and How it Works," emphasized that the government's "helping hand" refused to "relieve [veterans] of all responsibility."56 Similar appeals to personal responsibility earned support from conservatives in Congress. Like those conservatives, the Legion wanted to prevent FDR from capitalizing on veterans' legislation to expand his power. The concept of veterans' rights, not welfare entitlements, preserved the individual impetus for veterans to act on their own instead of depending on executive power. ${ }^{57}$

Both the Legion and NRPB wanted to enlarge veterans' programs; however, the Legion focused on the individual veteran and justified broad measures to protect his liberty. The NRPB's economy-wide perspective seemed, in the words of Representative Betrad W. Gearhardt (R-Calif.), to use the plight of veterans "to accomplish their objectives which have to do with social uplift." ${ }^{, 58}$ Rhetorical appeals to individualism and responsibility continued to assist returning veterans in their readjustment. However, the G.I. Bill of Rights' restricted focus limited its capacity for social reform. The G.I. Bill of Rights, operating under the Legion's expanded definition of a disabled veteran, withheld new powers from the federal government. As the G.I. Bill of Rights maintained continuity among eras of veterans' legislation, the Legion managed to unify conservatives and progressives in Congress.

The G.I. Bill's conception reveals its conservatism, an aspect overlooked by modern memory. However, the intentions to preserve a pre-war social contract and work within its limitations highlight how the appearances of government benevolence can misalign with their reality. The reality of the G.I. Bill relies on a lobby advancing its politics during a time of anxiety. The Legion capitalized on the need for change but promised to preserve traditional structures within the government as a justification to win the broad support it needed.

Representative John Rankin (D-Miss.) chaired the World War Veterans' Committee and shaped the bill to suit his values. A staunch segregationist, Rankin wanted to continue the social order abiding by the conventions of Jim Crow in the South. He refused to grant any federal agency with the power to encroach upon states' rights. ${ }^{59}$ Rankin and his Southern allies wrote a decentralized bill to ensure no agency pursued racial integration. During a House floor debate, Representative Ted Abernathy (D-Miss.) spoke on behalf of the Southern Democrat faction and claimed they "[did their] best throughout the bill_ ...on all possible features — to place all

\footnotetext{
${ }^{55}$ Bennett, When Dreams Came True, 3.

56 "The GI Bill of Rights: And How it Works," (Washington D.C.: Army Times, Daily News Building, June 22, 1944), 3.

${ }^{57}$ Frydl, The GI Bill, 79.

${ }^{58}$ Bennett, When Dreams Came True, 82.

${ }^{59}$ Ira Katznelson and Suzanne Mettler, “On Race and Policy History: A Dialogue about the G.I. Bill,” (Cambridge: Cambridge University Press, August 18, 2008), 524.
} 
authority possible back in the States. ${ }^{60}$ Segregationists, led by Rankin, ensured the G.I. Bill repressed social mobility for Black veterans.

Beyond protecting state implementation of the G.I. Bill, Rankin sought to limit access to the benefits given to white veterans. Title V of the bill granted unemployed veterans $\$ 20$ a week for up to 52 weeks as they looked for jobs. ${ }^{61}$ As drafted in the House and Senate version, Title V threatened wage inequality between white and Black veterans. ${ }^{62}$ Title $\mathrm{V}$ granted equal unemployment compensation regardless of race and allowed Black veterans the time to pursue higher-paying jobs than the first ones available, which were often as sharecroppers. ${ }^{63}$ Providing Black veterans with assistance to uplift themselves from impoverished conditions threatened white supremacy in the South. Rankin wanted assurance from the Veterans Administration (VA), which implemented the bill, that it would restrict Black veterans' access to benefits under Title V. ${ }^{64}$ The bill embodied Rankin's desire to preserve the prewar racial hierarchy in the South. The Senate passed a liberal version of the G.I. Bill, and Rankin refused to let the House even debate a bill similar to it. ${ }^{65}$ Rankin held the bill hostage in an executive session of the House World War Veterans Committee because he feared Black veterans would abuse Title V to live off the government or escape economic segregation, a form of de facto segregation by wealth and class among white and Black veterans. ${ }^{66}$ As Rankin claimed white veterans would reject "this socalled G.I. Bill" because of its equal treatment of white and Black veterans, he used the executive session to curb the Black veterans' access to unemployment compensation. ${ }^{67}$

After forcing executive revisions, Rankin protected the conservatism inherent in the final version of the bill. From April 18-May 3, 1944, the World War Veterans' Committee approached the bill in private to curb the liberalism within the Senate version of the bill. ${ }^{68}$ Threatening to destroy the entire G.I. Bill, Rankin pushed a more conservative draft through his committee to ensure the bill prevented federal agencies from using it to encroach upon states' rights. ${ }^{69}$ The committee consolidated the administration of the entire bill to one federal agency, the VA, and left the remaining powers to the states. ${ }^{70}$ While Rankin achieved a more restrictive Title V in committee and passed it through the House, he lost it while in conference committee with the Senate to write the final bill. ${ }^{71}$ The Legion persuaded Representative John Gibson (D-GA) to

\footnotetext{
60 Ted Abernathy speaking on HR 3280, 81 ${ }^{\text {st }}$ Cong, $1^{\text {st }}$ sess., Congressional Record 110 (May 12, 1944).

61 "The GI Bill of Rights: And How it Works," (Washington D.C.: Army Times, Daily News Building, June 22, 1944), 13.

${ }^{62}$ Frydl, The GI Bill, 134.

${ }^{63}$ Charles G. Bolte, “Our Negro Veteran,” (New York, Public Affairs Committee, Inc., 1947), 10.

${ }^{64}$ Frydl, The GI Bill, 7.

65 Ibid., 134.

${ }^{66}$ Karen Hofer Luecke, "What Shall Be Done When Victory is Won: The Cultural Foundations and Implications of the 1944 G.I. Bill of Rights,” PhD diss., George Mason University, Fall 2005, 138-9.

${ }^{67}$ Rankin to Hiller, Manager, Veterans Administration, Biloxi, Mississippi, April 25, 1944. HR 78.1-F39.1, Tray 17012, NARA, as quoted in Frydl, The GI Bill, 134.

${ }^{68}$ Ross, Preparing for Ulysses, 110.

${ }^{69}$ Frydl, The GI Bill, 142.

${ }^{70}$ Ross, Preparing for Ulysses, 110.

${ }^{71}$ Ibid., 117.
} 
vote against Rankin's language, and which extended a concession to the Senate and broke the tie within the House-Senate conference. ${ }^{72}$ However, Rankin's influence pervaded outside Congress. The Interstate Conference Commission helped write the final language of Title V and worked with Rankin to grant states interpretive control regarding Title V and according to the Comptroller General, "most of [its] disqualifying provisions." 73 States reserved the authority to block access to the breadth of entitlements, and many disqualifications affected Black veterans at a disproportionate rate. ${ }^{74}$

Rankin's leadership of the G.I. Bill before and after its passage prevented Black veterans from using the bill to advance in society. Pamphlets for Black veterans described Title V as an opportunity to pursue an attractive job offer. ${ }^{75}$ On the surface, the G.I. Bill created new opportunities for economic and social integration. However, states followed Rankin's lead and used the bill's decentralized structure to maintain economic segregation. ${ }^{76}$ Communications to veterans, such as a pamphlet entitled "Your "G.I. Bill of Rights" warned veterans that if they "fail, without cause, to accept suitable work when offered," states could revoke their unemployment compensation. ${ }^{77}$ The language made no distinction between Black and white veterans but left it to individual caseworkers to evaluate the cause for rejecting job offers. In such instances, white veterans almost always enjoyed more lenient interpretations when it came to their decisions over what job to accept. In that way, Rankin's decentralization of the G.I. Bill sustained Jim Crow practices across the South.

The VA controlled the federal administration of the bill. ${ }^{78}$ Endowing the VA with new jurisdiction over education, housing, loans, and unemployment appeared to expand its power and strength; however, it lacked the funding and staff to manage such programs. States implemented the G.I. Bill because the VA lacked the competency to administer it nationwide. ${ }^{79}$ Rankin, in private conversations with the VA Director, ensured that the administration preserved segregation by limiting consultation with other agencies that had progressive agendas ${ }^{80}$ Both Rankin and the Legion supported placing the bill in the VA to ensure their policy preserved the status quo - whether it be in segregation by race or by civilian and soldier status. ${ }^{81}$ The Legion framed their support for the VA in their membership newsletter as a means "to protect veterans from bureaucracy" and the excessive red tape associated with two agencies working in

\footnotetext{
72 Ross, Preparing for Ulysses, 117.

${ }^{73}$ Interstate Conference memo, July 3, 1944, Record Group 51, Bureau of the Budget, Records Re: Budgetary Administration in the VA, 1939-1952, (39.29a), NARA, Box 11, as quoted in Frydl, The GI Bill, 235.

${ }^{74}$ Frydl, The GI Bill, 250.

${ }^{75}$ Bolte, "Our Negro Veteran," 11.

${ }^{76}$ Frydl, The GI Bill, 250.

77 “'Your 'G.I. Bill of Rights:' Back to Civilian Life," (The National WW2 Museum), 50.

78 Altschuler, The GI Bill, 54.

${ }^{79}$ Frydl, The GI Bill, 5.

${ }^{80}$ Frydl, The GI Bill, 141.

${ }^{81}$ Ibid., 239.
} 
conjunction with each other. ${ }^{82}$ While the structure ensured minimal bureaucracy, it protected states' rights to administer the bill and thereby to maintain the status quo.

Congressional progressives challenged the consolidation under the VA and hoped to give other federal agencies authority. Senator Robert Wagner (D-NY) led the progressive opposition, which wanted multiple agencies to oversee G.I. entitlements. ${ }^{83}$ Wagner advocated making the G.I. Bill a step toward creating perennial welfare policy by endowing federal agencies with jurisdiction once granted to the states. ${ }^{84}$ If the G.I. Bill established a precedent for multiple agencies to administer education, housing, loan, and unemployment policy, related progressive legislation would have justification to overrule state policies. ${ }^{85}$ As Rankin restricted the federal authority over the G.I. Bill, he ensured later progressive bills must challenge federalist tradition, which would weaken their viability. The VA continued the social contract between the federal government and its veterans. While the G.I. Bill created material change for many veterans, the VA's control prevented institutional change that uplifted veterans regardless of race.

Together, Rankin and the Legion advocated for the VA to assume the administration of the bill for the benefit of veterans. The Legion wanted to protect the federal distinction between veterans and civilians. ${ }^{86}$ Believing the VA would preserve veterans' exceptionalism, the Legion supported the VA's authority over the G.I. Bill. ${ }^{87}$ The Legion collaborated with Rankin because he wanted to streamline benefits for veterans and protect them from superfluous paperwork. ${ }^{88}$ The alliance between Rankin and the Legion solidified the VA's control of the bill, and the progressive wing lost to the combined efforts to secure the G.I. Bill under weak leadership in Washington.

Despite the legislators' intentions to revert the economy to its prewar size, the bill facilitated growth. Veterans used their entitlements to obtain high-paying jobs, houses, and material comforts. ${ }^{89}$ The architects of the bill lacked the foresight to anticipate the economic transformations the bill soon catalyzed. ${ }^{90}$ Title II, which paid veterans' tuition for four years at any college or university that accepted them, kept veterans out of the job market for years as the economy grew. ${ }^{91}$ However, with the largest impact, Title II incited the growth of the middle class. $^{92}$

\footnotetext{
82 “World War II Veterans' Bill” The National Legionnaire, January 1944, found in The American Legion Digital Archive, https://archive.legion.org/, Accessed May 7, 2020, quote from page 4.

${ }^{83}$ Frydl, The GI Bill, 141.

${ }^{84}$ Ibid.

${ }^{85}$ Ibid., 190.

${ }^{86}$ Altschuler, The GI Bill, 59.

87 “World War II Veterans' Bill” The National Legionnaire, January 1944, found in The American Legion Digital Archive, https://archive.legion.org/, Accessed May 7, 2020, quote from page 3.

${ }^{88}$ Ibid., 2

${ }^{89}$ Dennis W. Johnson, The Laws that Shaped America: Fifteen Acts of Congress and their Lasting Impact, (Abingdon-On-Thames: Routledge Publishing, 2016), 176.

${ }^{90}$ Ibid., 228.

${ }^{91}$ Mosch, The G.I. Bill, 31.

${ }^{92}$ Johnson, The Laws that Shaped America," 202.
} 
Veterans flocked to colleges and universities across the nation. As Ira D. Scott, chief of the VA's Advisement and Guidance Division, advised that "adult education or training" prepare veterans for "occupational adjustment," veterans pursued education with practical applications. ${ }^{93}$ Servicemen sought employment as engineers, doctors, and teachers. ${ }^{94}$ However, these offers to join high-paying professions overlooked Black veterans. The VA organized no attempt to support colleges and universities unable to accommodate the influx of students. ${ }^{95}$ White schools often possessed the endowment and faculty to adapt; however, Black Colleges and Universities ${ }^{96}$ received little financial support from state governments. ${ }^{97}$ Without similar funding, Black schools lacked engineering and science departments and failed to expand their capacity for new students. ${ }^{98}$ Title II catapulted many white veterans into high-paying jobs, which integrated them into the middle class. ${ }^{99}$ However, segregated universities limited Black veterans' access to comparable education and resultant employment to white veterans. ${ }^{100}$

The G.I. Bill's impacts extended beyond collegiate enrollment. As veterans graduated college, many bought a house with the loan assistance provided under the G.I. Bill. ${ }^{101}$ World War II veterans owned almost half of new houses in the immediate postwar decade. ${ }^{102}$ Veterans' usage of their entitlements facilitated the growth of the American middle class, which looked like an era of prosperity. However, Black universities maintained their prewar enrollment numbers, and VA caseworkers directed Black veterans to lower-paying jobs than their white counterparts. ${ }^{103}$ Black veterans returned home to unequal acceptance into society. The G.I. Bill sought to reintegrate veterans into the economy and facilitated the segregation of veterans. The resultant growth in the economy exacerbated the antecedent inequality. The bill's language treated all veterans equal; however, individual states, universities, and caseworkers shaped each veterans' experience. While the middle class expanded and many white veterans enjoyed its comforts, Jim Crow pervaded society.

The American economy changed as veterans utilized the G.I. Bill. As men, regardless of economic class, attended university, white veterans encountered unprecedented social

\footnotetext{
${ }^{93}$ Ira D. Scott, Manuel of Advisement and Guidance, (Washington D.C.: United States Government Printing Office, 1945), 6.

94 Johnson, The Laws that Shaped America, 227.

${ }^{95}$ Frydl, The GI Bill, 310.

${ }^{96}$ I use this term to describe colleges and universities with all-Black student populations during the 1940s and 1950 s.

${ }^{97}$ Sarah Turner and John Bound, Closing the Gap or Widening the Divide: The Effects of the GI Bill and World War II on the Educational Outcomes of Black America, (Cambridge: National Bureau of Economic Research 2002 ), 7.

98 Ibid., 7.

${ }^{99}$ Hilary Herbold, "Never a Level Playing Field: Blacks and the GI Bill," The Journal of Blacks in Higher

Education 6, (1994/1995), 106.

100 Ibid., 107.

${ }^{101}$ Johnson, The Laws That Shaped America, 227.

${ }^{102}$ Kamil Kowalski, "What Shall We Do with Our Boys? An Impact of the GI Bill on the US Economy," Ethics in Economic Life, 29, no. 4 (2016), 175-6.

${ }^{103}$ Edward Humes, "How the GI Bill Shunted Blacks into Vocational Training, The Journal of Blacks in Higher Education 53, (2006), 97-8.
} 
mobility. ${ }^{104}$ However, the gap between white and Black Americans in educational attainment and economic class grew. ${ }^{105}$ The G.I. Bill preserved the segregated society veterans left behind. Veterans utilized the bill's entitlements, fulfilling the bill's intention to ward off a second Great Depression. The federal government continued to compensate "deserving" veterans for their losses during the war. Black veterans had little educational and economic opportunities before joining the military; the G.I. Bill afforded them with few opportunities upon return. States maintained the authority to select members of their privileged classes, which prevented the federal government from creating the social change the G.I. Bill appeared to create.

The Serviceman's Readjustment Act of 1944 transformed the American economy and appeared to reward veterans with unprecedented access to the middle class. However, the conservative formulation of the G.I. Bill of Rights and resultant law ensured more continuity than change. As the bill maintained the prewar social contract, it solidified the conclusion of the New Deal. World War II veterans' legislation coincided with the end of a progressive era and wielded an opportunity to empower the federal government to extend such politics for years to come. However, Rankin and the Legion maintained leadership of the bill to steer the legislation away from a liberal version. The bill's conservatism influenced how veterans saw themselves in relation to their government. The G.I. Bill influenced postwar policy by continuing the conservatism from before FDR's administration. The G.I. Bill preserved more of the prewar society than it changed. Despite its appearance of reform, the bill protected the social contract between veterans and their government.

${ }^{104}$ Bennett, When Dreams Came True, 238.

105 Turner, Closing the Gap or Widening the Divide, 25. 


\section{Bibliography}

$\underline{\text { Archival Sources }}$

The American Legion Digital Archive: https://archive.legion.org/

NAACP Papers: Group II, Series A, General Office Files, G.I. Bill of Rights, Folder: 1945-1949, $179 \mathrm{pp}$.

NAACP Papers: Group II, Series A, General Office Files, Veterans Administration, Folder: [Veterans Administration] 1944-[1945] 1948. 111pp.

\section{$\underline{\text { Primary Sources }}$}

“The American Presidency Project.” University of California Santa Barbara, June 26, 1944. https://www.presidency.ucsb.edu/documents/republican-party-platform-1944.

Bolte, Charles. “Our Negro Veteran.” New York: Public Affairs Committee, Inc. (1947): 1-31.

Bradley, Omar N. Decisions of the Administrator of Veterans'Affairs. Washington D.C: United States Government Printing Office, 1947.

“The GI Bill of Rights: And How It Works.” Army Times, June 22, 1944: 1-16.

Roel, Virgilo. The Education Revolution: A Salute to the American G I Bill of Rights of 1944 The Golden Era in Education for Mexican Americans - A Memoir of a World War II Veteran. Bloomington: iUniverse, Inc., 2009.

Schnapper, M.B. Veterans Information Directory, Washington D.C: Public Affairs Press, 1946.

Scott, Ira. Manuel of Advisement and Guidance. Washington D.C.: United States Government Printing Office, 1945.

Serviceman's Readjustment Act of 1944. HR 3280. 81 ${ }^{\text {st }}$ Cong., $1^{\text {st }}$ sess., Congressional Record 110, 4434-4461.

“Your 'G.I. Bill of Rights:' Back to Civilian Life.” The National WW2 Museum. 40-52.

\section{$\underline{\text { Secondary Sources }}$}

Altschuler, Glenn and Blumin, Stuart. The GI Bill: A New Deal for Veterans. New York City: Oxford University Press, 2009.

Bennet, Michael. When Dreams Came True: The GI Bill and the Making of Modern America. Park City: Brassey's Inc., 1996.

Frydl, Kathleen. The GI Bill. New York City: Cambridge University Press, 2009.

“GovTrack.us.: Accessed April 5, 2020. https://www.govtrack.us/congress/votes/78-1944/h120. 
Herbold, Hilary. "Never a Level Playing Field: Blacks and the GI Bill." The Journal of Blacks in Higher Education 6, (1994/1995): 104-108.

Held, Virginia and Mettler, Suzanne. Soldiers to Citizens: The G.I. Bill and the Making of the Greatest Generation. New York City: Oxford University Press, 2005.

Hindley, Meredith. "How the GI Bill Became Law in Spite of Some Veterans' Groups." HUMANITIES: The Magazine of the National Endowment for the Humanities 35, no. 4 (2014).

Humes, Edward. "How the GI Bill Shunted Blacks into Vocational Training." The Journal of Blacks in Higher Education 53, (2006): 92-104.

Johnson, Dennis. The Laws that Shaped America: Fifteen Acts of Congress and their Lasting Impact. Abingdon-On-Thames: Routledge Publishing, 2016.

Katznelson, Ira and Mettler, Suzanne. "On Race and Policy History: A Dialogue about the G.I. Bill.” American Political Science Association, 2008: 519-537.

Kowalski, Kamil. "What Shall We Do with Our Boys? An Impact of the GI Bill on the US Economy." Ethics in Economic Life 29, no. 4 (2016): 168-180.

Loss, Christopher. Between Citizens and the State: The Politics of American Higher Education in the $20^{\text {th }}$ Century. Princeton: Princeton University Press, 2012.

Luecke, Karen. "What Shall Be Done When Victory is Won: The Cultural Foundations and Implications of the 1944 G.I. Bill of Rights." George Mason University (2005): 1-305.

Mosch, Theodore. The G.I. Bill: A Breakthrough in Educational and Social Policy in the United States. Hicksville: Exposition Press, 1975.

Olsen, Keith. The G.I. Bill, the Veterans, and the Colleges. Lexington: The University of Kentucky Press, 1974.

Ross, David. Preparing for Ulysses: Politics and Veterans During World War II. New York City: Columbia University Press, 1969.

Skocpol, Theda. "America's First Social Security System: The Expansion of Benefits for Civil War Veterans." Political Science Quarterly 108, no. 1 (1993): 85-116.

Skocpol, Theda. "State Formation and Social Policy in the United States." The American Behavioral Scientist 35, no., (1992): 559-584.

"Sons of Union Veterans of the Civil War." January 9, 2014. http://www.suvcw.org/?page_id=167.

Turner, Sarah and Bound, John. Closing the Gap or Widening the Divide: The Effects of the GI Bill and World War II on the Educational Outcomes of Black America. Cambridge: National Bureau of Economic Research, 2002. 